\title{
The Meaning of Visual Language on Traditional House In Nias
}

\author{
Ariesa Pandanwangi ${ }^{1,}$ Krismanto Kusbiantoro ${ }^{2}$ \\ Program Studi Seni Rupa Murni, Universitas Kristen Maranatha ${ }^{1}$ \\ Program Studi Desain Interior Universitas Kristen Maranatha ${ }^{2}$ \\ ariesa.pandanwangi@maranetha.edu
}

\begin{tabular}{ll}
\hline \hline Keywords : & ABSTRACT \\
Visual language, Nias, & Indonesia memiliki beragam karya seni. Salah satunya \\
traditional house, tradition & yaitu bahasa rupa yang terdapat pada rumah tradisional. \\
& Pada umumnya, bahasa rupa yang ditampilkan dapat \\
berupa cerita figur-figur binatang, manusia, dan status & sosial masyarakat. Saat ini, semua bahasa rupa yang \\
& terdapat pada rumah adat di Nias belum \\
& terdokumentasikan dengan baik sehingga hal ini dapat \\
diadopsi untuk menciptakan bangunan modern di masa \\
yang akan datang. Tujuan penelitian ini untuk \\
mengungkapkan bahasa rupa yang terdapat pada rumah \\
tradisional Nias. Penelitian ini menggunakan metode \\
etnografi, eksplorasi lapangan, dan deskriptif. Pendekatan \\
penelitian yang digunakan adalah bahasa rupa. Hasil dari \\
penelitian ini adalah bahasa rupa yang terdapat pada \\
dinding kayu rumah tradisional bagian luar: figur \\
binatang yang ditempatkan horisontal, dan saling \\
berulang. Bahasa rupa di dalam rumah tinggal, terdapat \\
pada atap rumah dan pada bagian atas jendela depan \\
rumah. Figur yang ditampilkan di tengah-tengah atap \\
rumah adalah buaya (Ni'obuaya). Setiap figur yang \\
ditampilkan baik pada bagian luar rumah dan dalam \\
rumah adat mempunyai makna yang mendalam bagi para \\
penghuninya. \\
\hline
\end{tabular}

\section{INTRODUCTION}

A visual language is a tool to read picture. The picture that can be read is the forms that are still recognizable and not abstract. For examples, pictures of pre-historic paintings, traditional artworks, advertising, pictures made by kids, and so on (Tabrani, Primadi, 2014). In this research, the visual language that will be read is the pictures coming from traditional house in Nias, the island located on the western coast of Sumatra, Indonesia.

The area of Nias consists of two parts: the north and south. The traditional house located in the north is house on stilts with turtle shell-made roof and separately stands on oval sketch. In south, the traditional houses have a rectangle sketch and are in line horizontally and face-to-face. In this center between face-to-face houses, there is wide way used as public open space. In front of every traditional house, a grave of ancestors of Nias exists. This position of these houses is due to a good design planned before. 
This research focuses on one of traditional houses in South Nias inhabited by its local people. In the beginning, Nias people live in caves and on the trees (Duha, 2012). They do not have the knowledge yet to design their abode. As the time flies, the process of human beings' immigration seems to change their horizons to continually grow, especially for meeting the needs of abode. According to Pastor Johannes, the people coming to Nias are Chinese descendant. They come to it through Port of Singkuang, South Tapanuli. They bring an impact on extraordinary change of customs (bowo), laws (haka) and their enforcement (fondrako), as well as pedigrees (naga'oto niha) to be main things in Nias. Besides the impact, they also bring the ability of making wooden statues, standing stones, and megaliths, as well as stockbreeding and farming.

Other impacts of Chinese culture implemented in Nias traditional house of Omo Niha are a dragon head on the sword hilt, a front side of noble house, and some megaliths. Next development is that those impacts are able to revive Nias people: by having knowledge, they can become the man and woman with good intelligence.

The terminology of abode in Nias, according to Pastor Johannes citing his informant, comes from the word of $\mathrm{Owo}$ (boat) changing into the word of Gomo. This word finally changes into Omo (house) (Duham 2012:8). Some forms of traditional houses becoming abode are like a boat having dragon ornaments.

Boat and dragon, according to Rijadi, are adopted from a dwelling of surface water. Dragon as aquatic symbol derives a pattern of daily life and culture of people dwelling in Asia (Duha, 2012).

\section{METHOD}

Mixed method is used in this research. It is the combination of ethnography, field exploration, and descriptive method.

- $\quad$ Ethnography method is used to take data from field. To get valid data, we live together with local Nias people.

- $\quad$ Field exploration method is used to get valid data (Craswell, 2014). The inteded valid data are: (1) traditional houses that are still inhabited by local people in South Nias, (2) traditional buildings that are genuine so that visual language can be recognized and represented to be read (Tabrani, 2014). After getting field data, they are documented in digital photo or audio. After that, data are reduced and adjusted with the aim of this research. Finally, the processed data are analyzed by using visual language approach.

- Descriptive method is used to explain data obtained through photos, ornaments and interview during the research.

\section{Visual Language}

As stated by Tabrani (2005), to be able to read visual language, there are two terms related to the analysis. Firstly, content of image consisting of some objects in panel of drawing area. Secondly, way of image describing how to draw those some objects. If form of object is assumed important, object can be painted large. If the movement of objects is assumed essential, object can be repetitively painted. If transparency of objects is necessary, X-ray of inside objects can be painted.

\section{RESULTS AND DISCUSSIONS}




\section{The Context of Nias Culture}

The culture of Nias is not influenced by Hindu and Islamic religion. Nias people have already developed their own megalithic culture by scarifying pigs (Koentjaraningrat, 2004).

One of megalithic buldings, standing stone, or saita gari or benu or gowe zalava (in traditional language of Nias), can be seen in front of Nias traditional house. The existence of this standing stone shows a traditional party has ever done by its owner (Koentjaraningrat, 2004).

Although Nias people adopt megalithic culture with stone as material, their traditional houses use wood as material by using the construction system of stake and knot without nails. This system made is to give a flexibility of movement on building structure when earthquake happens. Tectonic earthquake is a source of morphologically forming Nias. Therefore, it is not weird if the fossil of shark teeth, obtained in the wood, is collected and available in the museum of Pusaka Nias.

The condition of nature is responded by Nias people by building houses on stilts that are able to move like boat that is able to fly on the shaking ground. In this construction system of house on stilts, the main poles and bean girders have a very main role. Therefore, the placing of animal paintings as ornament in Bawolato is dominantly found at the low part structure of the house. In addition, the inverse boat hull on the top part operates as roof to cover people from rain and light of sun. Thus, the tilted wall towards outside with opened windows ensures that air circulation occurs to solve the problem of hot weather and high humidity. Furthermore, a high rooftops and a steep tilted wall are the type of tropical house responding to climate challenge (Kusbiantoro, 2015:181).

\section{Visual Language of Traditional House in Bawolato}

Nias people are still alive in traditional house. Based on the interview conducted with one of heads of household, that also becomes a leader of village, a house that his family live exists for five generations. Therefore, young family living in this house does not clearly know the background of it, including the change of material made by the previous generation.

This research will discuss one of traditional houses lived by people over 100 years in Bawolato. The intended house is shown by Figure 1. This house belongs to non-noble descendant family, but it has uniqueness. The uniqueness is shown by many ornaments existing on panel board in front of the house until the rooms inside the house, and this condition is similar to the house where noble descendant family should live in

If compared with traditional house in Bawomataluo, the height of this house in Bawolato is similar. 


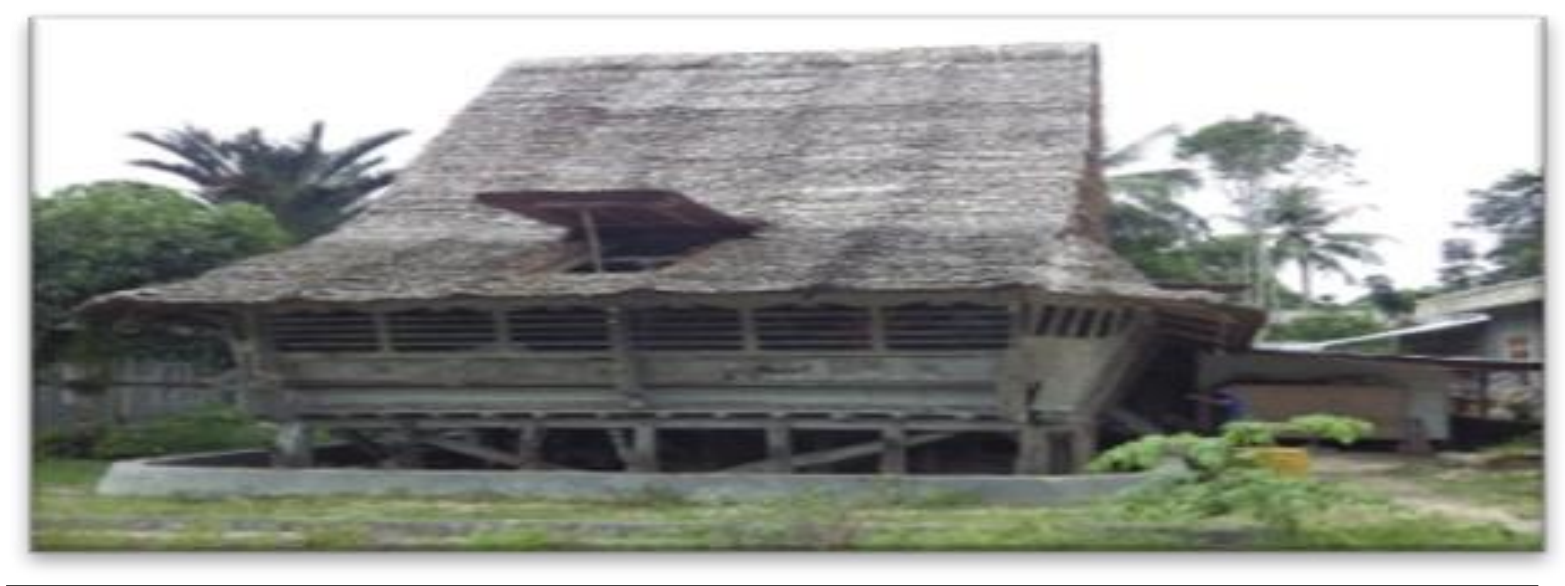

Figure 1: Front side of traditional house in Bawolato. Source: Researcher document

Two interesting things in this research are a form of roof (see Figure 1) reflecting a symbol of upper part of the world and a panel existing below ventilator (see Figure 2) reflecting a symbol of middle part of the world.

In Figure 2, every panel below the ventilator of the facade of this building displays a set of visual language telling a story of fauna that is horizontally arranged and can be read from left to right, and vice versa. This ventilator operates as air circulation and place to see someone coming to the house.

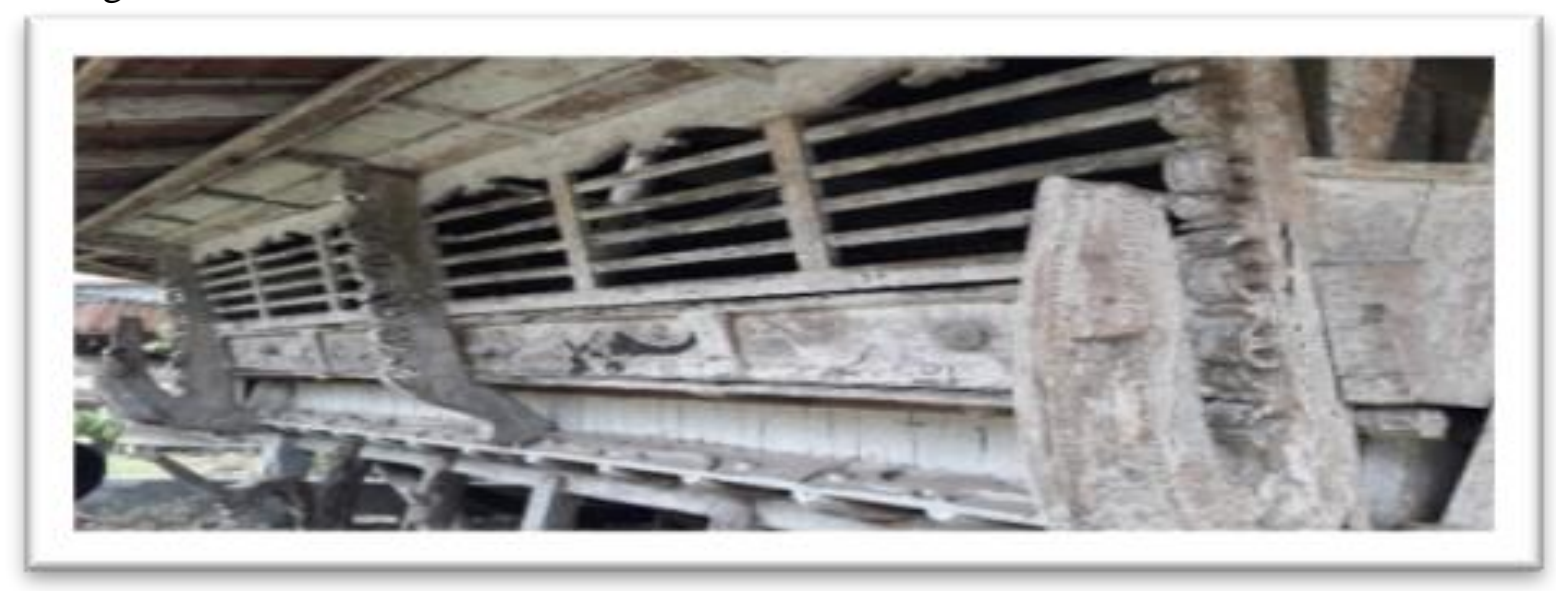

Figure 2: Outside wooden wall of traditional house in Bawolato. Source: Researcher document

There are four panels below the ventilator on a main part of traditional house (see Figure 3). On these four panels, animal figures are available. On the first and second panel, the pig and fish figure are respectively available. On the third and fourth figure, the lizard and two-legged animal exist, respectively. The pictures on the panels are in the face to-face pattern. 


\begin{tabular}{|c|c|c|c|}
\hline Panel 1 (left) & Panel 2 & Panel 3 \\
\hline & Fanel 4 (right) \\
\hline Face-to-face pattern & \multicolumn{2}{|c|}{} \\
\hline \hline
\end{tabular}

Besides two interesting things mentioned before, there are two things that needs to be an attention. The first one is the bottom part of this house (see Figure 4). The second one is a middle part of the traditional house facade (see Figure 5).

Figure 4 shows the bottom part of this house. This bottom part of this house reflects the under part of the world. In the bottom part, symbol of gender is available.

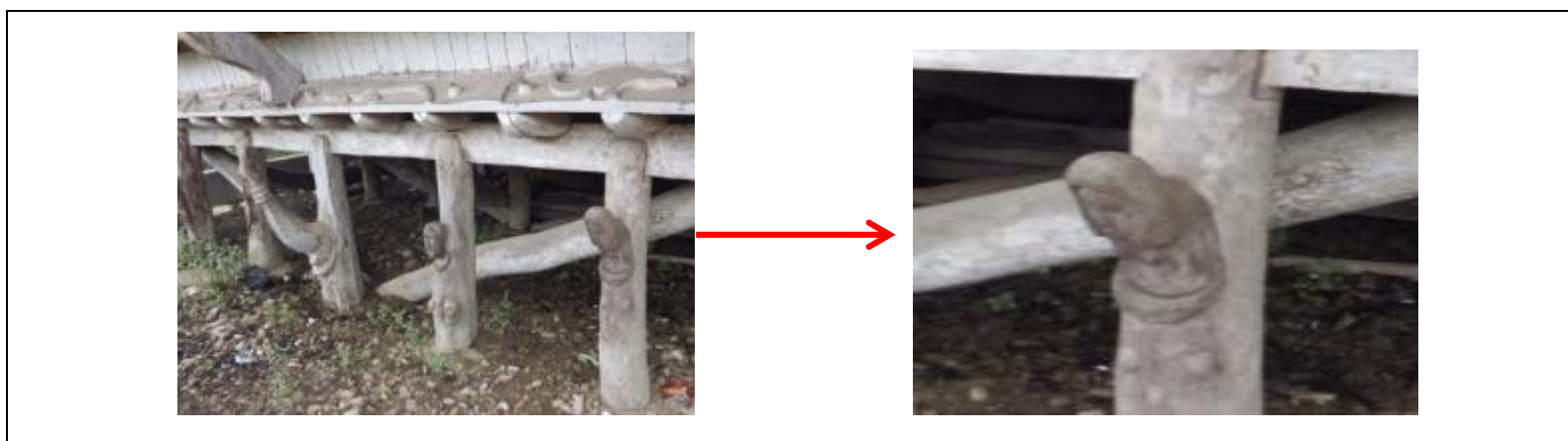

Figure 4. The bottom part of the traditional house Source: Researcher document

Figure 5 shows the middle part of the traditional house facade. The ornaments in this figure have a face-to-face pattern. These ornaments have various symbols, such as cosmology, social status, trust and customs. These symbols are delivered by Nias people in the form of moral messages in visual language.

\begin{tabular}{|l|l|}
\hline & Face-to-face pattern \\
\hline Face-to-face pattern & Face to face pattern \\
\hline $\begin{array}{l}\text { Figure 5. The ornament in middle part of the traditional House Facade } \\
\text { Source: Researcher document }\end{array}$
\end{tabular}


Physically, this traditional house has been a symbol of life and the survival custom. The existence of this traditional house in Nias shows an effort of preservation conducted by its owner. This effort should not stop at its owner, but it must be continued by next generation.

\section{CONCLUSION AND SUGGESTION}

The traditional houses inhabited by Nias people are a cultural product from their descendant. The forms of ornaments on traditional house in Bawolato are more dominated by visual language, located on building facade, referring to aesthetical paradox of pattern two (see Sumardjo, 2014): although two objects have a conflict, they are complementary each other. We thank Ministry of Research, Technology and Higher Education for funding this research and Universitas Kristen Maranatha for the support to do this research.

\section{REFERENCES}

Craswell, J.W. (2014). Penelitian Kualitatif \& Desain Riset, Edisi 3, Yogyakarta: Pustaka Pelajar.

Duha, N. (2012). Omo Niha: Perahu Darat di Pulau Bergoyang. Nias: Museum Pustaka Nias. Retrieved August 2017

Koentjaraningrat. (2002). Manusia dan Kebudayaan di Indonesia. Jakarta: Djambatan.

Kusbiantoro, K. \& Muliati, A. (2015) "Wolff Schoemaker's Ideas of Hybrid Topical Architecture in Bandung: A Critical Regionalism Approach, Region and Design: ChinaASEAN Architectural Space Design and Education Summit Forum Proceeding. Nanning, China: Guangxi Arts University.

Tabrani, P. (2014). Proses Kreasi-Gambar Anak-Proses Belajar. Jakarta: Erlangga.

Sumardjo, J. (2014). Estetika Paradoks (1 ed.). Bandung: Kelir. 